has enhanced its purely practical contributions to Indian life. Three years ago, the US National Research Council called its report on the remarkable properties of the tree's products Neem, A Tree for Solving Global Problems.

But the agricultural and medical properties of the neem extracts have increasingly been attracting the interest of international companies involved in agriculture, many of whom are keen to find new forms of pesticides that may cause less environmental damage than those discovered in the chemistry laboratory - and certainly carry a more benign image as a 'natural' product. Identifying the active ingredients through conventional scientific techniques, and incorporating the knowledge gained into products and processes aimed at the growing markets of the region, has often required substantial investment in research and development. And the companies choosing to make these investments have often chosen to protect this investment by taking out patents on their 'discoveries'.

Such actions, however, are now under fire. The use by Western-owned companies of a natural product whose properties have been known to indigenous communities for centuries has become a symbol for what critics describe as a form of 'genetic imperialism' - and as such, the focal point of a broader conflict about differing approaches to the ownership of knowledge about the natural world. Challenges are being launched in parallel in Europe and the United States on patents held by the multinational company W. R . Grace to various neem extracts that the company has successfully turned into marketable products (see page 95).

The sentiment behind the patent challenges is understandable. In the past, knowledge about the neem tree and the properties of substances derived from its seeds has been treated by native communities as a public good. In contrast, new knowledge, derived in the scientific laboratory and integrated into commercial products, becomes, through the patent system, a private commodity. While companies such as Grace will argue, with some justification, that this is merely the way in which the modern world works, it should hardly be surprised if the consequences of its actions should provoke the reaction that it has.

But is this sufficient for the patents to be revoked - as critics are now demanding? So far, their case is not persuasive. It is entirely correct that any patented discovery should be subject to rigorous scrutiny as to its genuine originality; but this does not, by definition, preclude patents that make use of earlier discoveries, whether patented or not. Similarly, if India wishes to demonstrate its vitality as a modern economy, it needs to embrace the essential role of the patent system, even in areas from which patents have traditionally been excluded. This is not to dismiss the legitimate concerns of those who claim that a lack of recognition by the patent system of indigenous (and largely unwritten) knowledge can discriminate unfairly against communities that have yet to embrace Western-style innovation. But the neem patents should be judged by the terms on which they were granted - not on the extent to which they conflict with traditional knowledge systems that have only a marginal role in the modern world.

\section{Save Down House}

\section{It will be a signal dishonour if Britain fails to save the house in which Darwin lived and wrote.}

SHELLEY's sonnet Ozymandias is a searing testament to the futility of remembrance. Shelley himself is buried near a pyramid raised to one Cestius, a Roman who would otherwise have been forgotten. Thomas Hardy later mused that even this posthumous remembrance would have faded were it not that the pyramid makes a convenient marker for the graves of the later romantics (Keats as well as Shelley). Like Hardy, Charles Darwin is buried in Westminster Abbey. The memories of both men live on in their writings, many of Darwin's in these pages, which points to another irony; without Darwin's influence on the likes of Thomas Huxley, the very existence of this journal would be in question.

If Darwin lives on in his literature, what is to become of his house? Down House, southeast of London, is suffering from more than half a century of neglect, which the Natural History Museum (NHM) in London would now rectify. The roof leaks and much of the interior needs renovation. Darwin's greenhouse is dilapidated, and the famous 'sandwalk' - laid down by Darwin as a place for thinking great thoughts - is now an overgrown woodland track.

How has it come to this? The Darwins bought the house in 1842, after which Darwin rarely strayed: he died there in 1882 . In 1929, the family sold it to a wealthy surgeon and philanthropist, who then left it to the Royal College of Surgeons (RCS), after which the rot set in. Things began to look up only in January 1993, when the NHM took on a 99-year lease, and set about raising the £3.2 million needed to restore the house and update its facilities for visitors. So far, more than $£ 0.5$ million has come from private subscription, and the NHM has now bid for $£ 2.4$ million from the 'Heritage' fund created by the National Lottery.

It is a scandal that the future of Down House should depend on this dubious form of voluntary taxation. More worrying is the let-out clause in the lease allowing that if, by January 1996, the NHM has not raised the funds to guarantee future maintenance of the house, it can be returned to the RCS. Given its track record, the RCS would probably let Down House collapse. Far better that the NHM should ask for the extra required to buy the house outright. The surgeons have shown too little interest in half a century to be regarded as worthy owners.

Down House may be a far cry from Ozymandias' Shattered Wreck, but why should we even care to save it? If Darwin, like Ozymandias or Cestius, were remembered for nothing more than his mere existence, that argument would carry some weight. It is because so much of Darwin survives, and his influence continues to be felt, that Down House is more than a gravestone to its most famous resident. 